\title{
Anileridine Hydrochloride
}

National Cancer Institute

\section{Source}

National Cancer Institute. Anileridine Hydrochloride. NCI Thesaurus. Code C65235.

The hydrochloride salt form of anileridine, an opioid receptor agonist belong ing to the piperidine class with analgesic activity. By binding to and activating opioid receptors in the central nervous sytem (CNS), anileridine mimics the endogenous opioids resulting in a decrease of nociceptve neurotransmitters and eventually an analgesic effect. 